\title{
Delineation of attenuation of oxidative stress and mutagenic stress by Murraya exotica L. leaves
}

\author{
Davinder Kaur, Arvinder Kaur and Saroj Arora*
}

*Correspondence:
sarojarora.gndu@gmail.com
Department of Botanical
and Environmental Sciences,
Guru Nanak Dev University,
Amritsar, Punjab 143005,
India

${ }^{*}$ Correspondence: sarojarora.gndu@gmail.com and Environmental Sciences, Amritsar, Punjab 143005, India

\begin{abstract}
Background: Murraya exotica L., a member of family Rutaceae is rich in biologically active secondary metabolites and also known for its ethnobotanical importance. With this in mind, the plant was chosen and leaves were extracted sequentially to obtain ethanol, hexane, chloroform, ethyl acetate, $n$-butanol and aqueous fractions. The extract/fractions were evaluated for total phenolic and flavonoid content by spectrophotometric methods. The UHPLC technique was employed for profiling the different polyphenolic compounds present in the extract/fractions. Furthermore, the extract/ fractions were analysed for the antioxidant and antimutagenic activities using different in vitro assays.
\end{abstract}

Results: It was observed that, among the different extract/fractions, ethyl acetate fraction exhibited maximum total phenolic content i.e. $119.6 \mathrm{mg}$ of GAE/g whereas chloroform fraction showed maximum total flavonoid content i.e. $323.5 \mathrm{mg}$ of RE/g. Likewise, UHPLC method also showed maximum number as well as amount of polyphenolic compounds in ethyl acetate fraction. It was further analyzed that the same fraction exhibited the maximum radical scavenging activity in all antioxidant assays. In Ames assay, ethyl acetate fraction again showed maximum antimutagenic activity of $97.70 \%$ against the 2-aminofluorene mutagen in TA100 tester strain of Salmonella typhimurium.

Conclusion: Overall, among all the extract/fractions, ethyl acetate fraction was observed to be highly effective in scavenging the free radical as well as reducing the mutagenic effect of the mutagen. The maximum bioactivities of the ethyl acetate fraction may be linked to the presence of high number of polyphenolic compounds as shown by spectrophotometric as well as UHPLC methods.

Keywords: Antioxidant activity, Antimutagenic activity, Epicatechin, Murraya exotica, Total phenolic content

\section{Background}

Various degenerative diseases are known to be caused by the acquisition of cascade of mutations provoked by mutagens. However, many mutagens may act through the endogenous generation of reactive oxygen species which interact with the nucleotides, disulphide bonds and polyunsaturated fatty acids. These interactions support the execution of oxidation process of biological compounds and therefore, act as initiators of various degenerative diseases such as cardiovascular, emphysema, inflammatory diseases, 
cataracts etc. To combat the devastating effect of reactive oxygen species, cellular system has evolved many endogenous enzymatic antioxidants like superoxide dismutase, glutathione, catalase, glutathione peroxidases and reductase as well as non-enzymatic antioxidants like vitamin C, tocopherols and tocotrienols etc. (Devi et al. 2015). However, in many conditions, exogenous supply of antioxidants becomes essential due to the depletion of endogenous antioxidants by the overproduction of reactive oxygen species (Robin et al. 2015). In addition to above, the mutagenic activities of carcinogens are also due to the generation of free radicals. As a result, the exploration of antioxidant potential of compounds carries great therapeutic significance (Del-Toro-Sánchez et al. 2014). Many synthetic antioxidants have the limited availability, affordability and harmful side effects which results in shifting the interest towards the natural products that are capable of neutralizing the free radicals without any side effects (Wong-Paz et al. 2015). Natural based antioxidants are believed to be driven out the harmful effects of oxidative damage especially by acting as enzyme inhibitors, or synergists, peroxide decomposers, singlet and triplet quenchers (Zahin et al. 2013). The antioxidant rich medicinal plants as known to be the reservoir of bio-protective compounds, exerts their effects to scavenge the free radicals via inducing phase II enzymes (Devi et al. 2015). Therefore, efforts are needed to explore the medicinal plant for the presence of protective compounds (Zahin et al. 2013).

Murraya exotica L. (commonly known as Chinese box or Jasmine orange) is an evergreen shrub, usually $2-3 \mathrm{~m}$ in height. $M$. exotica is the native of continental tropical Asia. It is extensively grown as an ornamental plant and for fencing the gardens (Ghani, 1998). The leaves of $M$. exotica have been reported to contain several secondary metabolites such as alkaloids, coumarins, flavonoids, phytosterols and dipeptides (Desoky et al. 1992; Barik and Kunda 1987; Barik et al. 1983; Ito and Furukawa 1987; Bishay et al. 1987; Desoky 1995; Ahmad and Begum 1987). The leaves have been reported to possess various properties such as stimulant, abortive and also used to treat dysentery, cuts, body aches, joint pain, diarrhea, venereal diseases (Kinoshuta and Fireman 1996; Parrotta 2001; Xiao and Wang 1991). Kong et al. (1985) reported the contraceptive properties of this plant. Yuehchukene, an alkaloid isolated from this plant showed the significant anti-implantation effects in female mice, when given orally or subcutaneously. Low dose of yuehchukene were also reported to have anti-tumor effects (Leung et al. 2000). A coumarin i.e. murrangatin, derived from the leaves showed antithyroid property (Khare 2007).

Keeping all in mind coupled with the fact that M. exotica is a rich source of polyphenolic compounds and has also not been much explored for the antioxidant and antimutagenic activity, the present study was conducted.

\section{Methods}

\section{Extraction and phytochemical analysis}

Fresh leaves (disease free) of M. exotica were collected in the month of December, 2011 from Mata Kaulan botanical garden of Guru Nanak Dev University campus, Amritsar. Plant specimen (accession no. 7315) was identified and deposited in herbarium of Department of Botanical and Environmental Sciences, Guru Nanak Dev University, Amritsar. Air dried leaves powder was extracted via using sequential extraction method to obtain 
the hexane, chloroform, ethyl acetate, $n$-butanol and aqueous fractions. The total phenolic and flavonoid content of extract/fractions was determined spectrophotometrically following the method of Singleton and Rossi (1965) and Kim et al. (2003) respectively. These extract/fractions were further subjected to UHPLC analysis for the profiling and quantification of polyphenolic compounds which was performed on Nexera UHPLC (Shimadzu) system equipped with C-18 Column. For this, $10 \mu \mathrm{l}$ of sample $[10 \mathrm{mg}$ extract or fraction/ml of methanol (HPLC Grade)] was filtered through 0.22 micron filters and injected into column with column temperature: $27^{\circ} \mathrm{C}$, flow rate: $1 \mathrm{ml} / \mathrm{min}$, mobile phase: water (A) and methanol (B), run time: 26 min. Identification of compounds was achieved through the comparison of their retention time and UV spectra with standards whereas quantification was done by using linear gradient elution method.

\section{Antioxidant activity}

The antioxidant activity of extract/fractions of $M$. exotica was measured in terms of hydrogen donating or radical scavenging ability via using DPPH radical scavenging assay (Blois 1958) and ABTS radical cation decolorization assay given by Re et al. (1999).

The reductive capacity of iron (III) was determined using the method of Oyaizu (1986), $\mathrm{Cu}$ (II)-Nc by CUPRAC assay given by Apak et al. (2007) and the molybdate ion by the method described by Prieto et al. (1999).

Hydroxyl radical scavenging ability of extract/fractions was determined by using DNA nicking assay which protect the supercoiled pBR 322 plasmid DNA from devastating effects of hydroxyl radicals generated by Fenton's reagent as described by Lee et al. (2002). Briefly, $0.3 \mu \mathrm{l}$ of plasmid DNA was mixed with $10 \mu \mathrm{l}$ of Fenton's reagent $\left(30 \mathrm{mM} \mathrm{H}_{2} \mathrm{O}_{2}\right.$, $50 \mu \mathrm{M}$ ascorbic acid, and $80 \mu \mathrm{M} \mathrm{FeCl}_{3}$ ) followed by the addition of $10 \mu \mathrm{l}$ of extract/fraction. The final volume of the mixture was adjusted to $20.5 \mu \mathrm{l}$ with distilled water. After incubate the reaction mixture for $30 \mathrm{~min}$ at $37{ }^{\circ} \mathrm{C}$, the DNA was loaded on a $1 \%$ agarose gel (prepared by dissolving $0.5 \mathrm{~g}$ of agarose in $50 \mathrm{ml}$ of $1 \mathrm{X}$ TBE Buffer followed by ethidium bromide staining) and electrophoresis was accomplished. Rutin was taken as a positive control and the densitometric analysis was done by using AlphaEaseFC 4.0 software for determining the hydroxyl radical scavenging ability of extract/fraction.

\section{Antimutagenicity assay}

The Ames Salmonella histidine reversion assay described by Maron and Ames (1983) with slight modifications given by Bala and Grover (1989) was used to elucidate the antimutagenic activity of different extract/fractions for TA98 (frame shift mutation) and TA100 (base pair substitution) tester strains of Salmonella typhimurium. TA98 and TA100 strains of S. typhimurium were procured from Prof. B.N. Ames, University of California, Berkeley. Different concentrations of extract/fractions (100, 250, 500, 1000 and $2500 \mu \mathrm{g} / 0.1 \mathrm{ml}$ of $\mathrm{DMSO} /$ plate) were tested against direct acting mutagens i.e. nitro-o-phenylenediamine (NPD, $20 \mu \mathrm{g} / 0.1 \mathrm{ml} \mathrm{DMSO} / \mathrm{plate})$ and sodium azide $\left(\mathrm{NaN}_{3}\right.$, $2.5 \mu \mathrm{g} / 0.1 \mathrm{ml} \mathrm{DMSO} / \mathrm{plate})$ for TA98 and TA100, respectively by using two experimental procedures, co-incubation and pre-incubation experiment. In the co-incubation experiment, a mixture of $0.1 \mathrm{ml}$ of bacterial culture, $0.1 \mathrm{ml}$ of mutagen, $0.1 \mathrm{ml}$ of different concentrations of extract/fractions was added to $2 \mathrm{ml}$ of top agar $(0.5 \% \mathrm{NaCl}, 0.5 \%$ Agar and $0.5 \mathrm{mM}$ Histidine/Biotine solution) which was then poured onto minimal 
agar plates. In the pre-incubation experiment, the mixture of $0.1 \mathrm{ml}$ of mutagen, $0.1 \mathrm{ml}$ of different concentrations of extract/fraction and $0.5 \mathrm{ml}$ of S9 mix (in case of indirect mutagen) was incubated for $30 \mathrm{~min}$ at $37{ }^{\circ} \mathrm{C}$. After incubation, the mixture along with $0.1 \mathrm{ml}$ of culture was added to $2 \mathrm{ml}$ top agar and then poured onto minimal agar plates. Concurrently, spontaneous (only $0.1 \mathrm{ml}$ bacterial culture in $2 \mathrm{ml}$ top agar), positive control $(0.1 \mathrm{ml}$ bacterial culture along with $0.1 \mathrm{ml}$ mutagen in $2 \mathrm{ml}$ top agar) and negative control $(0.1 \mathrm{ml}$ bacterial culture along with $0.1 \mathrm{ml}$ extract/fraction concentration in $2 \mathrm{ml}$ top agar) were also kept. Simultaneously, the antimutagenic activity of extract/fractions was also assessed against indirect acting mutagen 2-Aminofluorene (2AF, $20 \mu \mathrm{g}, 0.1 \mathrm{ml}$ $\mathrm{DMSO} /$ plate) in the presence of cytochrome based P450 metabolic system (S9 mix) for TA98 and TA100. The minimal agar plates were incubated at $37{ }^{\circ} \mathrm{C}$ for $48 \mathrm{~h}$ and number of histidine-independent revertant colonies was scored. The antimutagenicity was expressed as percentage decrease of reverse mutations as follow:

$$
\text { Inhibition }(\%)=((a-b) /(a-c)) * 100
$$

where $\mathrm{a}=$ number of histidine revertants induced by mutagen (positive control), $\mathrm{b}=$ number of histidine revertants induced by mutagen in the presence of extract/fraction, $\mathrm{c}=$ number of histidine revertants induced in the presence of extract/fraction alone and solvent (negative control). All the experiments were performed in triplicates.

\section{Statistical analysis}

The results are shown as means of the triplicates with standard error. Furthermore, statistical significance of the data was analyzed using the analysis of variance (one-way ANOVA) and Tukey's multiple comparison tests to determine the interactions and differences at $5 \%$ level of significance.

\section{Results}

\section{Extraction and phytochemical analysis}

In the present study, leaves of $M$. exotica were extracted with ethanol to obtain the mother ethanolic extract $(89.718 \mathrm{~g})$. The ethanolic extract $(22 \mathrm{~g})$ yielded 67.03, 18.10, $0.83,3.62$ and $6.59 \%$ of fraction when fractionated with hexane, chloroform, ethyl acetate, $n$-butanol and aqueous respectively as shown in Fig. 1 with maximum \% yield of hexane fraction. The total phenolic content was found highest in ethyl acetate fraction i.e. $119.6 \mathrm{mg} \mathrm{GAE} / \mathrm{g}$ and followed by $n$-butanol $>$ chloroform $>$ hexane $>$ ethanol $>$ aqueous fraction. Total phenolic content was determined by using the standard curve equation of $y=0.0005 x+0.0377, R^{2}=0.99$. Polyphenolic compounds like flavonoids have been labelled as "high level natural antioxidants" based upon their ability to scavenge free radicals and active oxygen species. Total flavonoid content was calculated from standard curve equation of $y=0.0006 x+0.0454$ with $R^{2}=0.99$. The highest flavonoid content of $323.5 \mathrm{mg} \mathrm{RE} / \mathrm{g}$ was measured in chloroform fraction as compared to other extract/fractions. The total flavonoid content in other extract/fractions was found in the order of ethanol $>$ hexane $>$ ethyl acetate $>n$-butanol $>$ aqueous fraction (Table 1).

The UHPLC analysis for polyphenolic compounds showed that sequential extraction of leaves results in the extraction of the different amount as well as number of polyphenolic compounds in different extract/fractions. The maximum number of polyphenolic 
Murrava exotica L. (Dried leaves $=817 \mathrm{~g}$ )

Extracted with ethanol (thrice)

Mother ethanolic extract $(89.718 \mathrm{~g})$

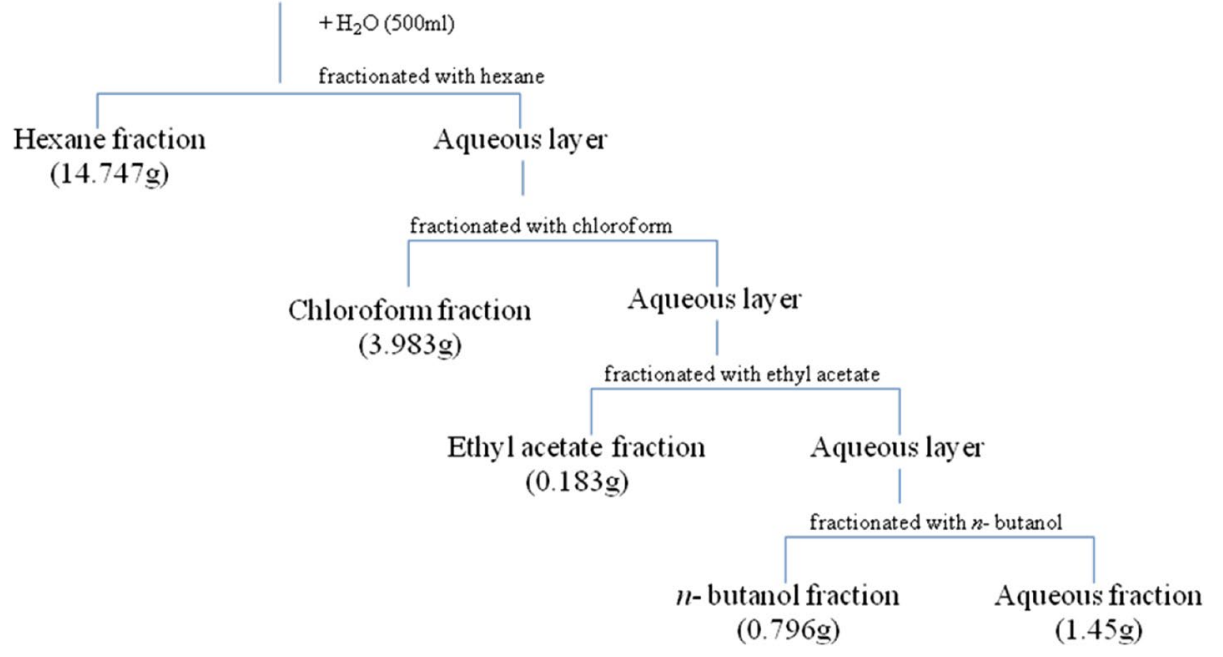

Fig. 1 Extraction and fractionation sketch of M. exotica leaves

Table 1 Extraction yield, total phenolic content (TPC) and total flavonoid content (TFC) in extract/fractions of $M$. exotica leaves

\begin{tabular}{lccc}
\hline Extract/fractions & Extraction yield (\%) & TPC (mg of GAE/g) & TFC (mg of RE/g) \\
\hline Ethanol & 10.98 & 29.6 & 282.66 \\
Hexane & 67.03 & 31.6 & 239.33 \\
Chloroform & 18.10 & 83.6 & 323.5 \\
Ethyl acetate & 0.83 & 119.6 & 96 \\
$n$-butanol & 3.62 & 99.6 & 54.33 \\
Aqueous & 6.59 & 27.6 & 19.33
\end{tabular}

compounds with high content of epicatechin (133.63 ppm) was identified in ethyl acetate fraction of leaf extract. A chromatograph obtained for other extract/fractions showed the presence of highest concentration of tert-butyl hydroquinone (35.50 and $175.44 \mathrm{ppm})$ in ethanol and $n$-butanol fractions respectively, kaempferol (186.44 ppm) in hexane fraction, rutin $(94.33 \mathrm{ppm})$ in chloroform fraction and chlorogenic acid (18.85 ppm) in aqueous fraction along with other polyphenols in minute concentrations as depicted in Table 2.

\section{Antioxidant activity}

The antioxidant potential of different extract/fractions was examined by employing the different in vitro antioxidant assays viz DPPH, ABTS, FRAP, CUPRAC and molybdate ion reduction assays.

The decolorizing activity following the trapping of unpaired electron of DPPH and ABTS radical cation was used as a measure of free radical scavenging activity (Fig. 2a, b). The radical scavenging activity of extract/fractions exhibited the dose dependent 
Table 2 UHPLC analysis of different extract/fractions of $M$. exotica (concentration in ppm)

\begin{tabular}{|c|c|c|c|c|c|c|c|c|}
\hline S. no. & Standard co & mpounds & $\begin{array}{l}\text { Ethanol } \\
\text { extract }\end{array}$ & $\begin{array}{l}\text { Hexane } \\
\text { fraction }\end{array}$ & $\begin{array}{l}\text { Chloroform } \\
\text { fraction }\end{array}$ & $\begin{array}{l}\text { Ethyl acetate } \\
\text { fraction }\end{array}$ & $\begin{array}{l}n \text {-butanol } \\
\text { fraction }\end{array}$ & $\begin{array}{l}\text { Aqueous } \\
\text { fraction }\end{array}$ \\
\hline 1. & Gallic acid & 664.017 & & & & 0.179 & 1.059 & 0.267 \\
\hline 2. & Catechin & 665.645 & & & & 4.605 & 12.343 & 17.229 \\
\hline 3. & $\begin{array}{l}\text { Chloro- } \\
\text { genic } \\
\text { acid }\end{array}$ & 333.184 & 0.308 & & & 5.544 & 29.72 & 18.859 \\
\hline 4. & Epicatechin & 665.418 & 3.483 & 0.389 & 58.787 & 133.63 & 13.41 & 0.275 \\
\hline 5. & Caffeic acid & 332.865 & 0.154 & & 0.175 & 2.911 & 13.376 & 2.985 \\
\hline 6. & $\begin{array}{l}\text { Umbellifer- } \\
\text { one }\end{array}$ & 333.016 & 0.371 & 0.371 & 2.102 & 73.238 & 8.569 & 0.22 \\
\hline 7. & $\begin{array}{l}\text { Coumaric } \\
\text { acid }\end{array}$ & 332.710 & & & 0.096 & 4.202 & 1.194 & 0.416 \\
\hline 8. & Rutin & 666.242 & 11.102 & 4.984 & 94.331 & 8.586 & 2.867 & \\
\hline 9. & Ellagic acid & 333.193 & & 0.323 & 8.078 & 11.348 & 17.703 & \\
\hline 10. & $\begin{array}{l}\text { Tert-Butyl } \\
\text { hydroqui- } \\
\text { none }\end{array}$ & 332.743 & 35.507 & 13.332 & 68.882 & 62.351 & 175.442 & 1.178 \\
\hline 11. & Quercetin & 332.449 & 0.817 & 0.194 & 0.972 & 11.777 & & \\
\hline 12. & Kaempferol & 332.296 & 3.966 & 186.443 & 6.176 & & & \\
\hline
\end{tabular}

Figures in italic showed the presence of highest amount of particular phenolic compound in respective extract/fraction

response in DPPH assay. The most effective free radical scavengers were found in ethyl acetate fraction with $90.77 \%$ decolorization at concentration of $1000 \mu \mathrm{g} / \mathrm{ml}$ whereas ascorbic acid (positive control) showed $91.96 \%$ of decolorization at $100 \mu \mathrm{g} / \mathrm{ml}$ concentration. Likewise, $n$-butanol, ethanol, aqueous, chloroform and hexane fractions exhibited the $70.05,45.28,28.27,20.25$ and $16.09 \%$ of decolorization activity respectively. In ABTS radical cation assay, all extract/fractions showed dose dependent free radical scavenging activity with highest potential $(92.80 \%)$ of ethyl acetate fraction which was found to be comparable to positive control (rutin). The ABTS radical cation decolorization activity was found in the order of ethyl acetate $>n$-butanol $>$ ethanol $>$ aqueous $>$ chloroform, and least in hexane fraction.

The reducing potential as exhibited by extract/fractions is shown in Fig. 2c-e. The Fe(III) reducing activity of all the extract/fractions was found to be dose dependent (Fig. 2c). Furthermore, at $1000 \mu \mathrm{g} / \mathrm{ml}$ concentration, the ethyl acetate fraction demonstrated maximum reducing potential of $55.48 \%$. Whereas, other extract/fractions also showed the reducing ability in the order of $n$-butanol $(36.07 \%)>$ ethanol $(31.88 \%)>$ hexane $(31.08 \%)>$ chloroform $(28.05 \%)$ and least in the aqueous fraction $(15.69 \%)$ at same concentration. Similarly, in cuprac assay, ethyl acetate fraction again exhibited the highest reducing power potential $(89.28 \%)$ as compared to other extract/ fractions at their highest concentration (Fig. 2d). However, rutin which was used as a positive control had comparable activity to ethyl acetate fraction and superior activity than other extract/fractions. In case of Molybdate ion reducing ability, the antioxidant activity was measured by using the standard curve of Gallic acid with regression equation of $y=0.002 x+0.086\left(R^{2}=0.94\right)$. The antioxidant activity by Molybdate ion reducing ability assay indicated that the highest antioxidant potential was determined in ethyl acetate fraction i.e. $95.83 \mathrm{mg} \mathrm{GAE} / \mathrm{g}$ dry weight of extract/fractions which was followed 

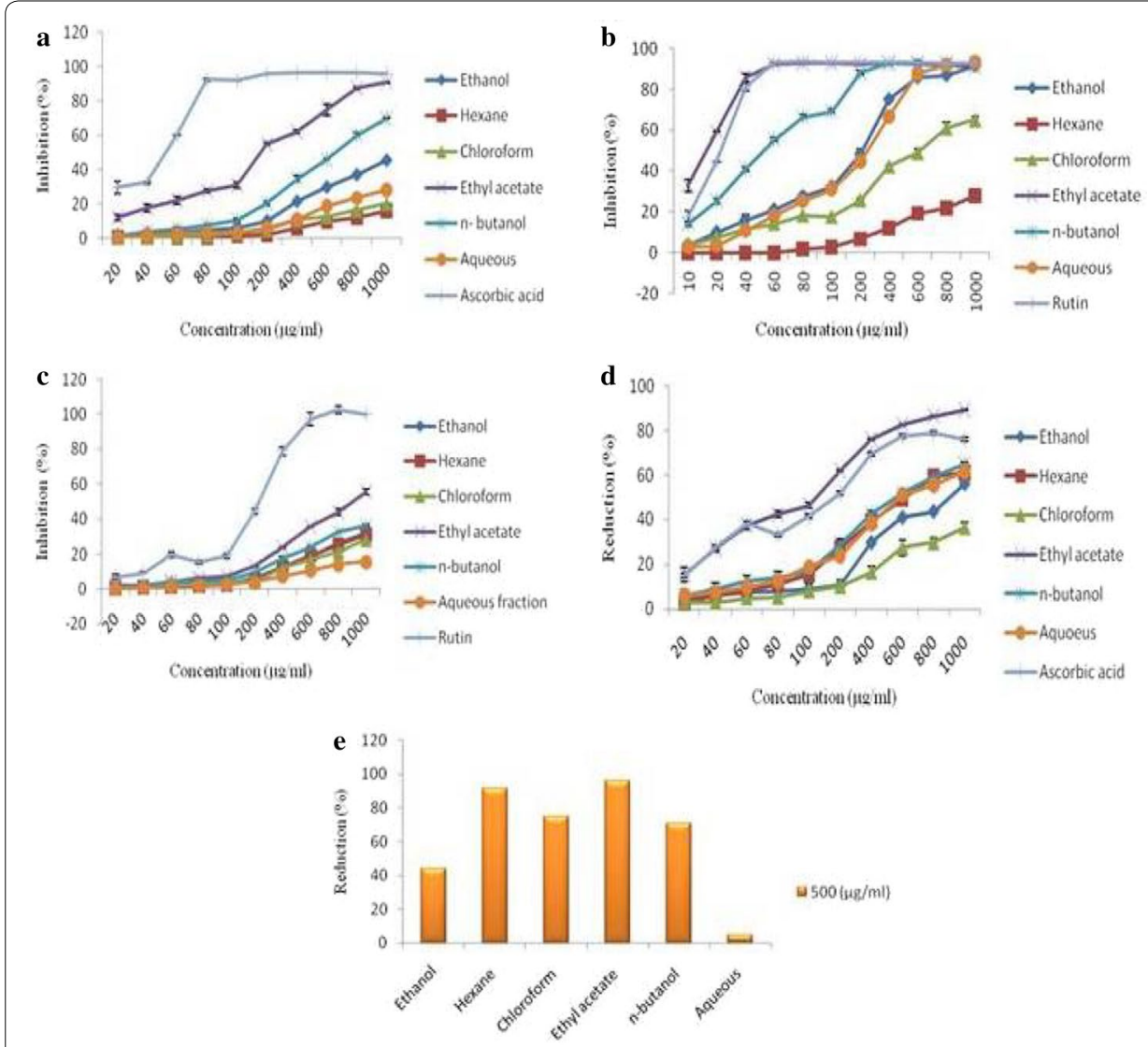

Fig. 2 Antioxidant activity of different concentrations of extract/fractions of $M$. exotica leaves accessed by DPPH radical scavenging assay (a), ABTS radical cation decolorization assay (b), FRAP assay (c), Cupric-lonReducing Antioxidant Capacity (CUPRAC) assay (d), Molybdate ion Reduction assay (e). Data expressed as mean of $\%$ inhibition \pm SE of triplicates

by hexane (91.5) $>$ chloroform (75) $>n$-butanol (70.83) $>$ ethanol (44.33) and aqueous fraction (4.66 mg GAE/g) at $500 \mu \mathrm{g} / \mathrm{ml}$ concentration as shown in Fig. 2e.

The hydroxyl radical scavenging ability of different concentrations of extract/fractions was observed by DNA nicking assay. As shown in Table 3 and Fig. 3, the presence of extract/fractions retained the maximum amount of supercoiled DNA in its native form (form I) by scavenging the hydroxyl radicals as generated by Fenton's reagent. From the densitometric analysis, it was found that ethyl acetate fraction significantly conserved the $52.8 \%$ of DNA in its native form by reducing the hydroxyl mediated breaking, conversion of supercoiled DNA into open circular (form II) and linear (form III) via scavenging the hydroxyl radicals in a dose dependent manner and thus providing the significant protection against oxidative stress.

\section{Antimutagenic activity}

On the basis of promising antioxidant and reducing activity, the different concentrations of extract/fractions were tested to explore the antimutagenic activity of $M$. exotica. All extract/fractions at different concentrations (100, 250, 500, 1000 and $2500 \mu \mathrm{g} / 0.1 \mathrm{ml} /$ 
Table 3 Densitometric analysis of DNA in plasmid nicking assay of extract/fractions of $\boldsymbol{M}$. exotica leaves

\begin{tabular}{|c|c|c|c|c|c|c|c|c|}
\hline \multirow[t]{2}{*}{ Form of DNA } & \multicolumn{8}{|c|}{ Amount of DNA (\%) } \\
\hline & 1 & 2 & 3 & 4 & 5 & 6 & 7 & 8 \\
\hline \multicolumn{9}{|l|}{ Ethanol extract } \\
\hline Form I & 69.8 & - & 30.7 & 52.1 & 51.8 & 49.8 & 43.8 & 41.5 \\
\hline Form II & 30.2 & 71.4 & 54.9 & 40.2 & 40.5 & 42.5 & 50.0 & 53.0 \\
\hline Form III & - & 28.6 & 14.4 & 7.8 & 7.7 & 7.7 & 6.2 & 5.5 \\
\hline \multicolumn{9}{|c|}{ Hexane fraction } \\
\hline Form I & 81.6 & - & 17.7 & 43.2 & 41.2 & 42.0 & - & - \\
\hline Form II & 18.4 & 72.6 & 66.5 & 46.4 & 53.3 & 43.0 & 79.6 & 73.4 \\
\hline Form III & - & 27.4 & 15.9 & 10.4 & 8.9 & 15.0 & 20.1 & 26.6 \\
\hline \multicolumn{9}{|c|}{ Chloroform fraction } \\
\hline Form I & 68.3 & - & - & - & - & - & - & - \\
\hline Form II & 31.7 & 63.15 & 48.1 & 49.1 & 55 & 55.4 & 54.2 & 55.7 \\
\hline Form III & - & 36.85 & 51.9 & 50.9 & 45 & 44.6 & 45.8 & 44.3 \\
\hline \multicolumn{9}{|c|}{ Ethyl acetate fraction } \\
\hline Form I & 79.1 & - & 39.1 & 58.2 & 55.9 & 55.2 & 52.9 & 40.3 \\
\hline Form II & 20.9 & 76.3 & 45.8 & 35.4 & 35.2 & 36.0 & 38.1 & 49.7 \\
\hline Form III & - & 23.7 & 15.1 & 6.4 & 8.9 & 8.8 & 9.0 & 10.0 \\
\hline \multicolumn{9}{|c|}{$n$-butanol fraction } \\
\hline Form I & 69 & - & - & - & - & - & - & - \\
\hline Form II & 31 & 51.9 & 45.2 & 47.3 & 48.6 & 51 & 52.6 & 55.3 \\
\hline Form III & - & 48.1 & 54.8 & 52.7 & 51.4 & 49 & 47.4 & 44.7 \\
\hline \multicolumn{9}{|c|}{ Aqueous fraction } \\
\hline Form I & 72.4 & - & - & - & - & - & - & - \\
\hline Form II & 27.6 & 65.1 & 50.4 & 51.1 & 51.6 & 52.8 & 53.8 & 56.3 \\
\hline Form III & - & 34.9 & 49.6 & 48.9 & 48.4 & 47.2 & 46.2 & 43.7 \\
\hline
\end{tabular}

a Lane 1: pBR322 DNA + distilled water; lane 2: pBR322 DNA + distilled water + Fenton Reagent (FR); lane 3: pBR322

DNA + FR + Rutin; lane 4-8: pBR322 DNA + FR + Extract/fraction (1000, 800, 600, 400 and $200 \mu \mathrm{g} / \mathrm{ml}$ respectively)

plate) were found to be non-toxic and non-mutagenic for TA98 and TA100 strains in the absence as well as presence of $\mathrm{S} 9 \mathrm{mix}$.

Against TA98, the antimutagenic response of chloroform fraction was found to be significant with $74.04 \%$ decrease in $\mathrm{NaN}_{3}$-induced mutagenicity and $96.31 \%$ decrease in 2-AF-induced mutagenicity (Fig. 4c). Linear regression was found to be strong with S9 $\left(R^{2}=0.938\right)$ as compared to without $S 9\left(R^{2}=0.920\right)$. On the contrary, the ethyl acetate fraction significantly $(\mathrm{p} \leq 0.005)$ decrease the number of $\mathrm{His}^{+}$revertants induced by sodium azide by $49.07 \%\left(R^{2}=0.934\right)$ and 2 -AF by $97.70 \%\left(R^{2}=0.991\right.$, highest among all extract/fractions) for TA100 as depicted in Fig. 5d. The antimutagenic effect was found to be more pronounced in pre-incubation than co-incubation in the presence of S9 mix (Figs. 4, 5). The linear regression analysis showed the presence of strong correlation between the extract/fraction dose and antimutagenic response against the mutagen with the $\mathrm{R}^{2}$ value ranges from 0.701 to 0.991 . The whole experimentation was also scrutinized statically for interaction and difference by two-way ANOVA which showed the significant difference between the different concentrations as well as different modes of experimentations (Pre and co-incubation mode) at $5 \%$ level of significance. 


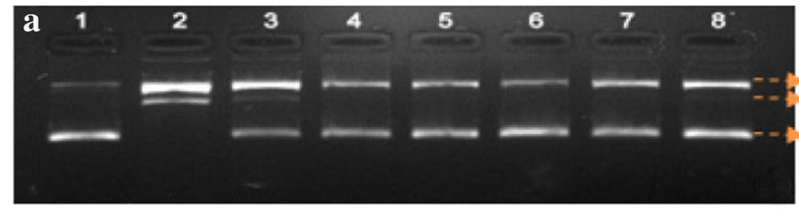

Frim II (Dorble nitked DNA)

FormIII (Siqu nited DNA)

FumI (Soperoiled DNA)

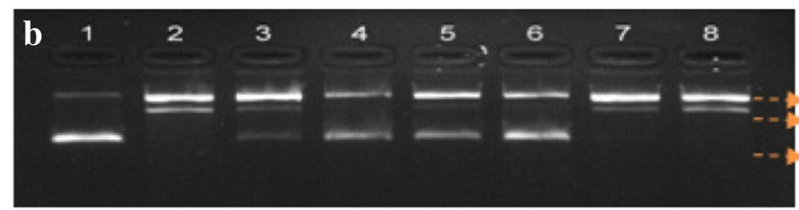

Fom II (Dorble nitzed DNA)

FrmIII (Eingle nited DNA) FomI (Sppariled DNA)

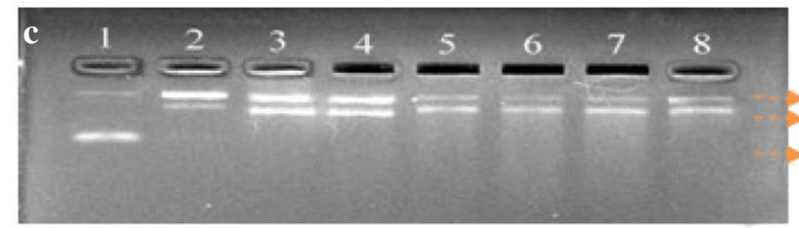

Fram II (Droble nitzed DNA)

FumIII (Enqu nited DNA)

Fom I (Soperailed DNA)

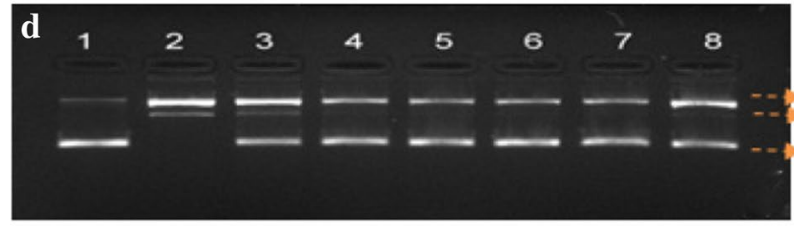

Fom II (Dople n'ted DNA) FomIII (Siy) nited DNA) FomI (Stpero:iled DNA)

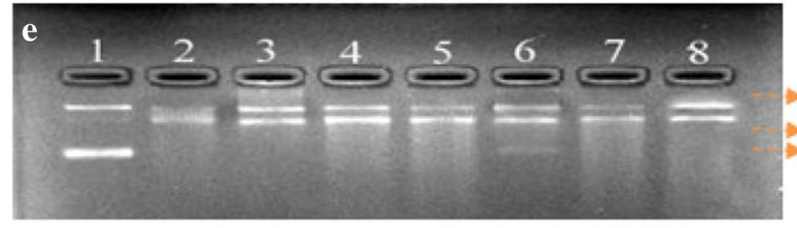

FormII (Dorble nitzed DNA)

FomIII (Singe nitzed DNA)

FomI (Stprex: ild DNA)

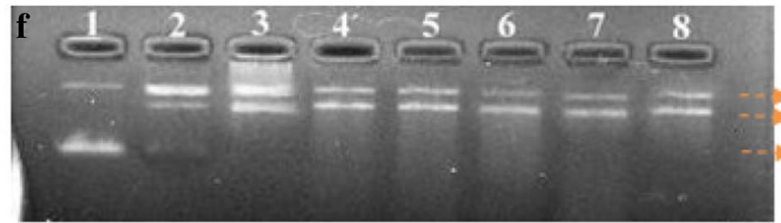

Fomn I (Double nized DNA)

FomIII (Singe nited DNA) Fam I (Stpreailed DNA)

Fig. 3 DNA nicking assay for non site-specific 'OH scavenging activity of ethanol extract (a), hexane (b), chloroform $(\mathbf{c})$, ethyl acetate $(\mathbf{d}), n$-butanol $(\mathbf{e})$, aqueous fractions $(\mathbf{f})$ of $M$. exotica leaves. Lane 1 represents: pBR322 DNA + distilled water; lane 2 pBR322 DNA + distilled water + Fenton Reagent (FR); lane 3 pBR322 DNA + FR + Rutin; lane 4-8 pBR322 DNA + FR + Extract/fraction (1000, 800, 600, 400 and 200 mg/ml respectively)

\section{Discussion}

Oxidative stress induced diseases can be prevented by the removal of free radicals from circulation via good chelators. Devi et al. (2015) revealed that the plant metabolites like polyphenols are effective free radical scavenges and can be easily metabolized inside the body without any harmful effects. So an attempt has been made to find out the phytoconstituents especially polyphenolic and flavonoids and then elucidate the antioxidant and antimutagenic activity of extract/fractions of $M$. exotica. 


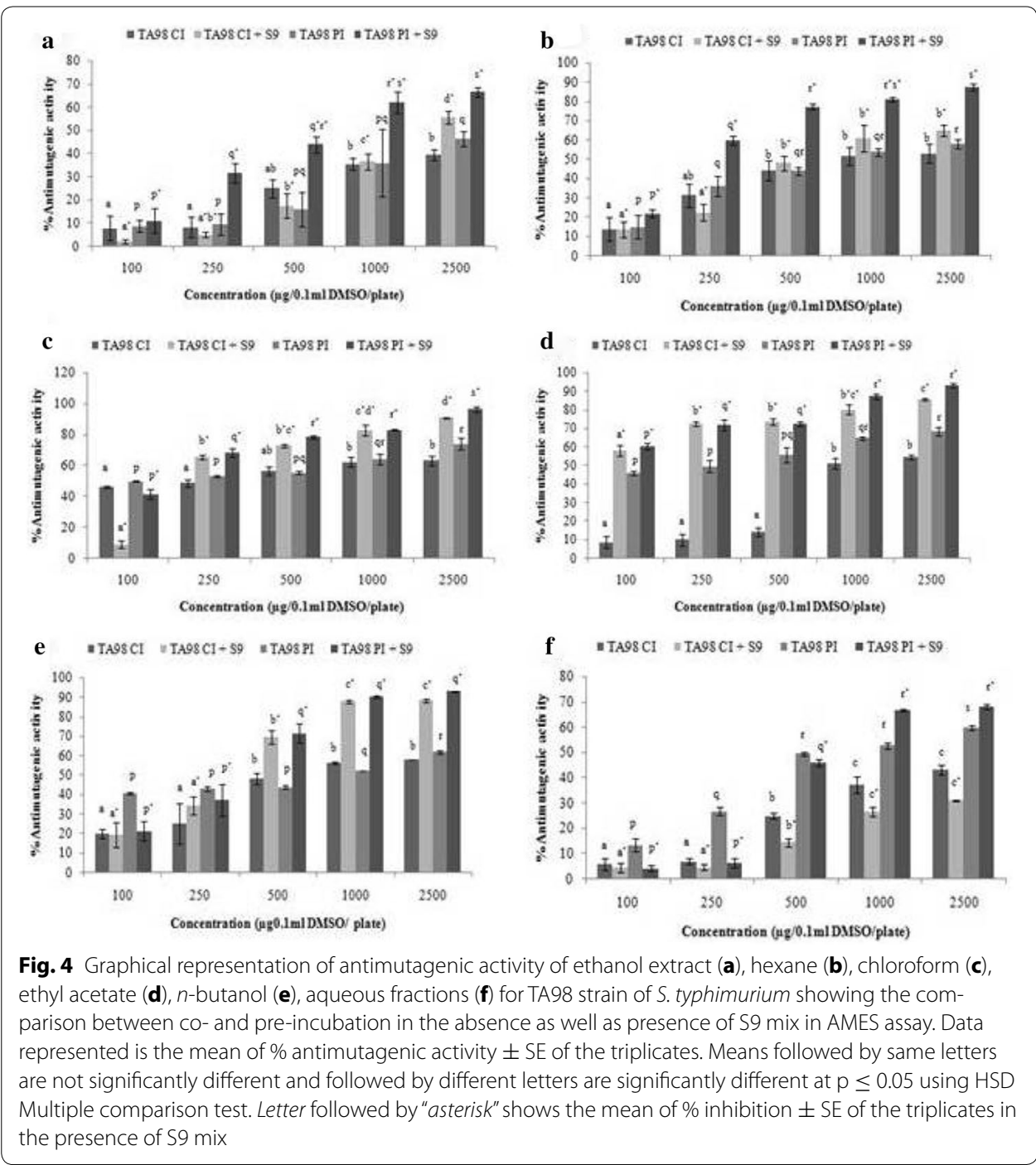

A critical analysis of results showed that ethyl acetate fraction was rich in polyphenolic compounds and exhibited the maximum antioxidant and antimutagenic activities. There is plethora of reports available in literature which corroborates the results obtained in present study. The studies conducted by Gautum et al. (2012) and Khatun et al. (2014) showed the presence of phenols and flavonoids in different species of Murraya. The total phenolic content and total flavonoid content was found to be varying in different extract/ fractions due to fractionation of leaves with different solvents. In the present study, the ethyl acetate fraction of $M$. exotica leaves were found to have high total phenolic content which might be responsible for the maximum antioxidant activity in all tested assays. The study conducted by Zahin et al. (2013) also emphasizes the antioxidant potential of different extract/fractions of $M$. koenigii over the range of $0-120 \mu \mathrm{g} / \mathrm{ml}$ and found that benzene fraction exhibited the maximum antioxidant potential. A redox potential of the phenolic compounds that contributes to the antioxidant property mainly include free radical scavenging activity, transition-metal-chelating activity and singlet-oxygenquenching activity (Ciz et al. 2010) and thus, involve in the termination of free radical 

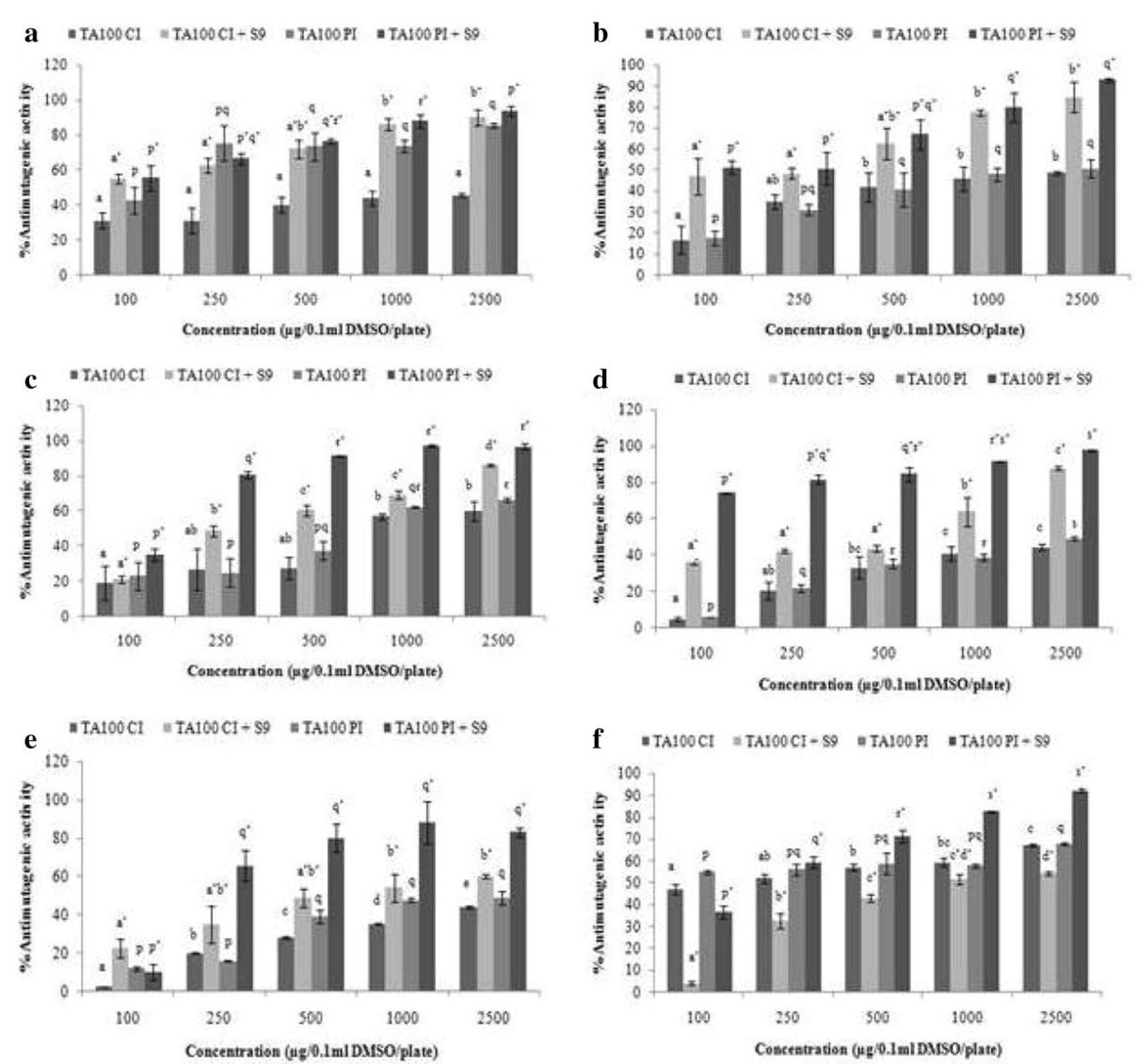

Fig. 5 Graphical representation of antimutagenic activity of ethanol extract (a), hexane (b), chloroform (c), ethyl acetate (d), $n$-butanol (e), aqueous fractions (f) for TA100 strain of S. typhimurium showing the comparison between co- and pre-incubation in the absence as well as presence of S9 mix in AMES assay. Data represented is the mean of \% antimutagenic activity \pm SE of the triplicates. Means followed by same letters are not significantly different and followed by different letters are significantly different at $p \leq 0.05$ using HSD Multiple comparison test. Letter followed by "asterisk" shows the mean of \% inhibition \pm SE of the triplicates in the presence of $\$ 9 \mathrm{mix}$

chain reactions (Ningappa et al. 2008). At certain concentration of reactive oxygen species, the $\mathrm{OH}$ bond of polyphenols is broken and released the hydrogen ion which contributes towards the antioxidant potential by further quenching the nucleophilic radicals (Devi et al. 2015). So, the most significant radical scavenger determinant in the polyphenols mainly includes a free 3-hydroxyl group, 3',4'-catechol structure and a 4-oxo group on the $C$ ring. These structural properties are also present in epicatechin which might act as principle components in ethyl acetate fraction (high phenolic content) for its maximum activity in all antioxidant assays. Literature reviews also revealed a positive correlation between the phenolic content and the antioxidant activity in mushroom (Chang et al. 2007). A correlation was also found in agreement with the finding of Zhang et al. (2011) and Anagnostopoulou et al. (2005) that showed the potent antioxidant ability of seventy polymethoxylated flavonoids (PMFs) isolated from leaves of $M$. exotica.

Oxidative damage in pBR322 DNA strands induced by hydroxyl radicals generated by Fenton reagent results in the formation of nicked circular form (form II, formed by single stranded scission) and linear form (form III, formed by double stranded breaks). By 
chelating the redox-active transition metal ions, polyphenols might be acts as protecting agents against the devastating effects of oxidative damage (Prakash et al. 2007). Polyphenols with catechol, 4-oxo and $\mathrm{OH}$ group also inhibited the Fenton induced oxidation via scavenging the radicals (Ciz et al. 2010). The study conducted by Kumar et al. (2010) also revealed that the methanol extract of $M$. exotica with high phenolic (510 mg GAE/g dry weight of extract) and flavonoid content (55.4 mg RE/g dry weight of extract) was found to be effective in plasmid nicking assay. Similarly, in our study, the ethyl acetate fraction with high phenolic content showed the significant protection against damage induced by hydroxyl radicals.

The difference in antioxidant activity of different extract/fractions might be ascribed to the presence of different chemical constituents. Overall, antioxidant activity of extract/ fraction may be the result of synergic interactions of polyphenolic compounds with one another, and/or other compounds present in the extract/fraction (Hatano et al. 1989; Laranjinha et al. 1995; Van-Acker et al. 1998).

Mutations are considered as the early step in carcinogenesis. Endogenous and exogenous agents can inhibit the acquisition of genetic mutations via modulating the phase I and phase II enzymes, blocking reactive species and thus maintains the structure of DNA. So, a genetic test "AMES assay" was conducted to prove the antimutagenic activity of $M$. exotica. In the antimutagenic studies, the extract/fractions were found to be nonmutagenic that may be due to the fact that constituents does not interact directly with DNA and did not block the DNA synthesis, leading to the induction of SOS mechanism (Arif et al. 2004). Our finding of dose dependent effect of extract/fractions in Ames assay was in agreement with other findings (Aqil et al. 2008). In 2013, Zahin et al. also demonstrated the dose dependent antimutagenic activity of polyphenolic rich benzene fraction of M. koenigii in Ames Salmonella mutagenicity assay. It exhibited the antimutagenicity activity of $72-86 \%$ against various mutagens i.e. sodium azide, methyl methanesulfonate, benzo(a)pyrene and 2-aminofluorene at maximum tested concentration for both TA98 and TA100 strains of S.typhimurium. In our study, ethyl acetate fraction was found to be exhibit the maximum antimutagenic potential. High amount of polyphenolic compounds in ethyl acetate fraction may contribute to its high inhibitory activity against 2AF-induced mutagenicity for TA100 strain. Modulators in the ethyl acetate fraction might interfere with the metabolic activation of 2-AF by altering the structure and function of cytochrome p-450 enzyme and providing the protection against chemically induced mutagenesis. Cytochrome $\mathrm{p}-450$ enzyme catalyze the conversion of $2-\mathrm{AF}$ into N-hydroxy-2-aminoflourene which interacts directly with DNA and induces the mutagenesis (Zahin et al. 2014). The present study reveals the direct inactivation of mutagen, before gene mutation occurred. In 2011, Schwarz et al. also found that estradiol-dependent cancer might be regulated by polyphenolic compounds. Mixture of antioxidants has been reported in various plants like Castela texana and Stevia pilosa with antimutagenic properties. These secondary compounds have the ability to scavenge the reactive oxygen species, reduce the mutagenicity, improve the alkylated DNA damage and therefore, halt the cellular mutability (Del-Toro-Sánchez et al. 2014). A scientific research that mainly focused on developing the phyto-originated medicine was found to be very efficient in providing prophylaxis against mutation and cancer (Sarac et al. 2015). 
So, the best way to reduce the increased cancer prevalence rate is the incorporation of chemopreventing agents especially of plant origin into diet (Basgedik et al. 2015).

\section{Conclusion}

The present study shows that the M. exotica leaves are rich source of phenols and flavonoids. Among the different extract/fractions obtained by sequential extraction method, ethyl acetate fraction exhibited maximum antioxidant as well as antimutagenic activities. The same fraction was found to be rich in different polyphenolic and flavonoid compounds. These observations indicate the potential of the plant to be further taken up to analyze it in battery of biological assays, so that the plant can be used further in chemotherapy.

\section{Authors' contributions}

DK carried out the experimental work and also drafted the manuscript, the second author AK helped in performing the antimutagenic assay where as corresponding author Dr. (Prof.) SA, critically reviewed the manuscript. So, all the three authors have contribution. All authors read and approved the final manuscript.

\section{Acknowledgements}

The authors are highly thankful to University Grants Commission (UGC), New Delhi for providing financial support. The authors are also grateful to Mr. Robin, GNDU for helping us in statistical analysis of data.

\section{Competing interests}

The authors declare that they have no competing interests.

Received: 8 March 2016 Accepted: 29 June 2016

Published online: 11 July 2016

\section{References}

Ahmad ZA, Begum S (1987) Colensenone and colensanone (non-diterpene oxide) from Murraya exotica Linn. Indian Drugs 24:322

Anagnostopoulou MA, Kefalas P, Kokkalou E, Assimopoulou AN, Papageorgiou VP (2005) Analysis of antioxidant compounds in sweet orange peel by HPLC-diode array detection-electrospray ionization mass spectrometry. Biomed Chrom 19(2):138-148

Apak R, Guclu K, Demirata B, Ozyurek M, Celik SE, Bektasoglu B, Berker Kl, Ozyurt D (2007) Comparative evaluation of various total antioxidant capacity assays applied to phenolic compounds with the CUPRAC assay. Molecules 12:1496-1547

Aqil F, Zahin M, Ahmad I (2008) Antimutagenic activity of methanolic extracts of four ayurvedic medicinal plants. Indian J Exp Biol 46(9):668-672

Arif JM, Kunhi M, Siddiqui YM, El Sayed KA, Orabi KY, Al-Hazzani A, Al-Ahdal MN, Al-Khodairy FM (2004) Differential modulation of benzo[a]pyrene-derived DNA adducts in MCF-7 cells by marine compounds. Int J Cancer Prev 1:259-268

Bala S, Grover IS (1989) Antimutagenicity of some citrus fruits. Mutat Res 222:141-148

Barik BR, Kunda AB (1987) A cinnamic acid derivative and a coumarin from Murraya exotica. Phytochemistry 26(12):3319-3321

Barik BR, Dey AK, Chatterjee A (1983) Murrayatin, a coumarin from Murraya exotica. Phytochemistry 22(10):2273-2275

Basgedik B, Ugur A, Sarac N (2015) Antimicrobial, antioxidant and antimutagenic properties of Iris albicans. Ind Crop Prod 69:480-484

Bishay DW, El-Sayyad SM, Abd El-Hafiz MA (1987) Phytochemical study of Murraya exotica L. (Rutaceae) Methoxylated flavonoids of the leaves. Bull Pharm Sci 10:55-70

Blios MS (1958) Antioxidant determinations by the use of a stable free radical. Nature 26:1190-1200

Chang HY, Ho YL, Sheu MJ, Lin YH, Tseng MC, Wu SH, Huang GJ, Chang YS (2007) Antioxidant and free radical scavenging activities of Phellinus merrillii extracts. Bot Stud 48:407-417

Ciz M, Cizova H, Denev P, Kratchanova M, Slavov A, Lojek A (2010) Different methods for control and comparison of the antioxidant properties of vegetables. Food Control 21:518-523

Del-Toro-Sánchez CL, Bautista-Bautista N, Blasco-Cabal JL, Gonzalez-Ávila M, Gutiérrez-Lomeli M, Arriaga-Alba M (2014) Antimutagenicity of methanolic extracts from Anemopsis californica in relation to their antioxidant activity. eCAM. doi:10.1155/2014/273878

Desoky EK (1995) Phytosterols from Murraya exotica. Phytochemistry 40(6):1769-1772

Desoky EK, Kamel MS, Bishay DW (1992) Alkaloids of Murraya exotica L. (Rutaceae) cultivated in Egypt. B-FOPCU 30:235-238

Devi HP, Mazumber PB, Devi LP (2015) Antioxidant and antimutagenic activity of Curcuma caesia Roxb. rhizome extracts. Toxicol Rep 2:423-428

Gautam MK, Gangwar M, Nath G, Rao CV, Goel RK (2012) In-vitro antibacterial activity on human pathogens and total phenolic, flavonoid contents of Murraya paniculata Linn. leaves. Asian Pac J Trop Biomed 2(3):S1660-S1663 
Ghani A (1998) Medicinal plants of Bangladesh, Ist edn. The Asiatic Society of Bangladesh, Dhaka

Hatano T, Edamatsu R, Hiramatsu M, Moti A, Fujita Y, Yasuhara T, Yoshida T, Okuda T (1989) Effects of tannins and related polyphenols on superoxide anion radical, and on 1,1-diphenyl-2-picrylhydrazyl radical. Chem Pharm Bull 37:2016-2021

Ito C, Furukawa H (1987) Constituents of Murraya exotica L. Structure elucidation of new coumarins. Chem Pharm Bul 35(10):4277-4285

Khare CP (2007) Indian medicinal plants—an illustrated dictionary. Springer, New York, p 425

Khatun A, Rahman M, Jahan S (2014) Preliminary phytochemical, cytotoxic, thrombolytic and antioxidant activities of the methanol extract of Murraya exotica LINN. leaves. Orient Pharm Exp Med 14:223-229

Kim D, Jeong S, Lee CH (2003) Antioxidant capacity of phenolic phytochemicals from various cultivars of plums. Food Chem 81:321-326

Kinoshuta T, Fireman K (1996) Highly oxygenated flavonoids from Murraya Paniculata. Phytochemistry 4:1207-1210

Kong YC, Cheng KF, Cambie RC, Waterman PG (1985) Yuehchukene: a novel indole alkaloid with anti-implantation activity. J Chem Soc Chem Commun 2:47-48

Kumar A, Kaur R, Arora S (2010) Free radical scavenging potential of some Indian medicinal plants. J Med Plants Res 4(19):2034-2042

Laranjinha J, Vieira O, Madeira V, Almeida L (1995) Two related phenolic antioxidants with opposite effects on vitamin E content in low density lipoproteins oxidized by ferrylmyoglobin: consumption versus regeneration. Arch Biochem Biophys 323:373-381

Lee JC, Kim HR, Kim J, Jang YS (2002) Antioxidant property of an ethanol extract of the stem of Opuntia ficus-indica var. saboten. J Agric Food Chem 50:6490-6496

Leung TW, Gheng G, Chui CH, Ho SK, Lau FY, Tiong JK, Poon TC, Tang JC, Tse WC, Cheng KF, Kong YC (2000) Yuehchukene, a bis-indole, and cyclophosphamide are active in breast cancer in vitro. Chemotherapy 46(1):62-68

Maron DM, Ames BN (1983) Revised methods for Salmonella mutagenicity test. Mutat Res 13:173-215

Ningappa MB, Dinesha R, Srinivas L (2008) Antioxidant and free radical scavenging activities of polyphenol-enriched curry leaf (Murraya koenigii L.) extracts. Food Chem 106:720-728

Oyaizu M (1986) Studies on product of browning reaction: antioxidant activity of products browning reaction prepared from glucoseamine. Japn J Nutr Diet 44:307-389

Parrotta AJ (2001) Healing plants of peninsular India. CABI publishing, New York

Prakash D, Singh BN, Upadhyay G (2007) Antioxidant and free radical scavenging activities of phenols from onion (Allium сера). Food Chem 102:1389-1393

Prieto P, Pineda M, Aguilar M (1999) Spectrophotometric quantitation of antioxidant capacity through the formation of a phosphomolybdenum complex: specific application to the determination of vitamin E. Anal Biochem 269:337-341

Re R, Pellegrini N, Proteggente A, Pannala A, Yang M, Rice-evans C (1999) Antioxidant activity applying an improved ABTS radical cation decolorization assay. Free Radic Biol Med 26:1231-1237

Robin, Arora S, Vig AP (2015) Inhibition of DNA oxidative damage and antimutagenic activity by dichloromethane extract of Brassica rapa var. rapa L. seeds. Ind Crop Prod 74:585-591

Sarac N, Ugur A, Sen B (2015) Invitro antimutagenic activity of Vitex angus-castus L. essential oils and ethanolic extracts. Ind Crops Prod 63:100-103

Schwarz D, Kisselev P, Schunck W, Roots I (2011) Inhibition of 17 $\beta$-estradiol activation by CYPIAl: genotype and regioselective inhibition by St. John's Wort and several natural polyphenols. Biochim Biophys Acta 1814(1):168-174

Singleton VL, Rossi JA (1965) Colorimetry of total phenolics with phosphomolybdic phosphotungstic acid reagents. Am J Enol Vitic 16:144-158

Van-Acker SABE, Van-Balen GP, van-den-Berg DJ, Bast A, Van-der-Vijgh WJF (1998) Influence of iron chelation on the antioxidant activity of flavonoids. Biochem Pharmacol 56:935-943

Wong-paz JE, Esquivel JCC, Rodrfguez-Herrera R, Carrillolnungaray ML, Lopez LI, Nevarez-rMoorillon GV, Aguilar CN (2015) Total phenolic content, in vitro antioxidant activity and chemical composition of plant extracts from semiarid Mexican region. Asian Pac J Trop Med 8(2):104-111

Xiao PG, Wang NG (1991) Can ethnopharmacology contribute to the development of anti-fertility drugs? J Ethnopharmacol 32(1-3):167-177

Zahin M, Aqil F, Husain F, Ahmad I (2013) Antioxidant capacity and antimutagenic potential of Murraya koenigii. BioMed Res Int. doi:10.1155/2013/263509

Zahin M, Ahmad I, Gupta RC, Aqil F (2014) Punicalagin and ellagic acid demonstrate antimutagenic activity and inhibition of Benzo(a)pyrene induced DNA adducts. BioMed Res Int. doi:10.1155/2014/467465

Zhang J, Li N, Che YY, Zhang Y, Liang S, Zhao M, Jiang Y, Tu P (2011) Characterization of seventy polymethoxylated flavonoids (PMFs) in the leaves of Murraya paniculata by on-line high-performance liquid chromatography coupled to photodiode array detection and electrospray tandem mass spectrometry. J Pharm Biomed Anal 56(5):950-961 